\title{
HER2 EXPRESSION AND RESPONSE OF BREAST CANCER TO ADJUVANT CHEMOTHERAPY
}

\author{
Alinta Hegmane* and Uldis Vikmanis** \\ ${ }^{*}$ Rīga Eastern University Hospital, Latvian Oncology Centre, Hipokrāta iela 4, Rīga, LV-1079, LATVIA; \\ e-mail: alinta@btv.Iv. \\ ${ }^{* *}$ Faculty of Medicine, University of Latvia, Šarlotes iela 1a, Rīga, LATVIA
}

Communicated by Ruta Muceniece

\begin{abstract}
Expression of the human epidermal growth factor receptor type 2 (HER2) in breast cancer patients may predict response to anthracycline or non anthracycline-based adjuvant chemotherapy. A total of 192 breast cancer patients diagnosed at the Latvian Oncology Centre from January 2002 to August 2005 were included in the study. Patients had histopathologically confirmed breast cancer, had undergone radical surgery and received at least four courses of adjuvant chemotherapy. HER2 expression was evaluated by immunohystochemical analysis. Median follow-up time was 32.1 months. In HER2 negative patients, the mean time to recurrence was 26.9 months (SD 1.465; 95\% Cl 23.9-29.4) for patients received antracycline-based chemotherapy and 33.2 months (SD 1.308; 95\% Cl 30.6-35.8) in the CMF chemotherapy group ( $\mathrm{P}<0.05)$. These HER2 negative patients could be treated with a less toxic regimen of CMF. In HER2 overexpressed patients receiving anthracycline based chemotherapy, mean time to recurrence was 30 months (SD 2.170; 95\% Cl 25.7-34.4) compared with 29.2 months (SD 1.965; 95\% Cl 25.4-33.1) in patients who received CMF, but the difference was not significant $(\mathrm{P}>0.05)$.
\end{abstract}

Key words: breast cancer, HER2, adjuvant chemotherapy.

Overexpression of the human epidermal growth factor receptor type 2 (HER2) occurs in approximately 15 to 25 percent of breast cancer cases, and is associated with agressive behavior of the tumour (Slamon et al., 1989). It has been suggested that HER2 overexpression in breast cancer cells can identify patients who will not respond to CMF chemotherapy (Gusterson et al., 1992), and who can benefit from anthracycline-containing regimens (Paik et al., 1998; De Laurentiis et al., 2001; Knoop et al., 2005; Pritchard et al., 2006).

To test this hypothesis, we studied medical records of 192 breast cancer patients treated at the Latvian Oncology Centre from January 2002 to August 2005, to determine whether expression of HER2 in primary breast cancer cells predicts efficacy of particular adjuvant chemotherapy in breast cancer patients.

Surgical tumour samples were evaluated at the State Pathology Centre of Latvia. Immunohistochemical (IHC) analysis was performed on paraffin-embedded tissue. ER and PR was determined according to DAKO LSAB+ methodology. Expression of the HER2 protein was measured by immunohistochemical analysis following the procedure for the HercepTest (Dako Corporation, Glostrup, Denmark) according to the manufacturers protocol. A negative HER2 test is defined as an IHC result of 0 or $1+$ for cellular membrane pro- tein expression. A positive HER2 test is defined as an IHC result of $3+$ cell surface protein expression. An IHC result $2+$ is equivocal, some but not all of $2+$ samples may have undergone HER2 gene amplification and thus they require additional testing by FISH or CISH (Wolff et al., 2007).

HER2 was determined in all patients. The frequencies of HER2 expression were as follows: $30.2 \%$ (58 patients) were HER2 positive (3+ IHC), 54.7\% (105 patients) HER2 negative (0/1+ IHC), $15.1 \%$ (29 patients) had an equivocal result $(2+$ IHC). The latter were excluded from further analysis, because it was not possible to determine HER2 gene amplification routinely in Latvia and thus HER2 status could not be determined correctly in this group of patients.

The clinical, pathologic and biologic characteristics of the breast cancer patients and the distribution of HER2 expression are listed in Table 1 . There was no significant difference between women with HER2 overexpression and those without overexpression, except for a shift toward higher grade among those whose tumours exhibited HER2 overexpression.

Treatment. Radical mastectomy was performed in $74 \%$ of cases (142 patients), and breast-conserving surgery plus axillary dissection in 26\% (50 patients). Patients received at least four cycles of adjuvant chemotherapy with (FAC 
Table 1

PATIENT AND TUMOUR CHARACTERISTICS ACCORDING TO HER2 STATUS

\begin{tabular}{|c|c|c|c|c|}
\hline Variable & $\begin{array}{l}\text { HER2 } 0 / 1+ \\
\mathrm{n}=105, \%\end{array}$ & $\begin{array}{l}\text { HER2 2+ } \\
\mathrm{n}=29, \%\end{array}$ & $\begin{array}{l}\text { HER2 3+ } \\
\mathrm{n}=58, \%\end{array}$ & $P$-value \\
\hline Median age & 51.9 & 51.4 & 54 & 0.82 \\
\hline $\begin{array}{l}\text { Tumour size } \\
\qquad \begin{array}{l}\mathrm{cm} \\
2-5 \mathrm{~cm} \\
5 \mathrm{~cm}\end{array}\end{array}$ & $\begin{array}{c}36(34.2) \\
47(44.8) \\
22(21)\end{array}$ & $\begin{array}{c}15(51.7) \\
13(44.8) \\
1(3.5)\end{array}$ & $\begin{array}{c}14(24.1) \\
36(62.1) \\
8(13.8)\end{array}$ & 0.198 \\
\hline $\begin{array}{l}\text { Nodes } \\
\text { negative } \\
\text { positive }\end{array}$ & $\begin{array}{l}42(40) \\
63(60)\end{array}$ & $\begin{array}{l}13(44.8) \\
16(55.2)\end{array}$ & $\begin{array}{l}29(50) \\
29(50)\end{array}$ & 0.21 \\
\hline $\begin{array}{l}\text { Hormone receptors } \\
\text { (ER, PR) } \\
\quad \text { negative } \\
\text { positive }\end{array}$ & $\begin{array}{l}40(38.1) \\
65(61.9)\end{array}$ & $\begin{array}{c}7(24.1) \\
22(75.9)\end{array}$ & $\begin{array}{l}25(43.1) \\
33(56.9)\end{array}$ & 0.53 \\
\hline $\begin{array}{l}\text { Grade } \\
\qquad \begin{array}{l}1 \\
2 \\
3 \\
\text { Unknown }\end{array}\end{array}$ & $\begin{array}{c}0 \\
37(35.2) \\
41(39) \\
27(25.8)\end{array}$ & $\begin{array}{c}0 \\
13(44.8) \\
9(31) \\
7(24.2)\end{array}$ & $\begin{array}{c}3(5.2) \\
18(31) \\
26(44.8) \\
11(19)\end{array}$ & 0.062 \\
\hline
\end{tabular}

(5-fluorouracil $500 \mathrm{mg} / \mathrm{m}^{2}$, doxorubicin $50 \mathrm{mg} / \mathrm{m}^{2}$, cyclophosphamide $500 \mathrm{mg} / \mathrm{m}^{2}$ intravenously day 1 , every three weeks) or FEC (5-fluorouracil $500 \mathrm{mg} / \mathrm{m}^{2}$, epirubicin 60 $\mathrm{mg} / \mathrm{m}^{2}$, cyclophosphamide $500 \mathrm{mg} / \mathrm{m}^{2}$ intravenously on day 1 every three weeks) or without (CMF (cyclophosphamide $600 \mathrm{mg} / \mathrm{m}^{2}$, methotrexate $40 \mathrm{mg} / \mathrm{m}^{2}$, 5-fluorouracil 600 $\mathrm{mg} / \mathrm{m}^{2}$ intravenously days 1 and 8 every four weeks) anthracyclines to meet the study inclusion criteria. Anthracyclinebased chemotherapy was received by $62.9 \%$ of patients in the HER2 negative and $41.4 \%$ of patients in the HER 2 positive group $(P<0.05)$, CMF was received by $37.1 \%$ and $58.6 \%$ of patients, respectively. Postoperative irradiation was performed on $78.1 \%$ of patients: radiotherapy on $81 \%$ of patients in the HER2 negative and $72.4 \%$ in the HER2 positive group. Irradiation was given to all patients treated with breast-conserving surgery (50 Gy to residual breast plus a $10 \mathrm{~Gy}$ boost). Postmastectomy irradiation was received by patients if tumour was greater than $5 \mathrm{~cm}$ (46 Gy to chest wall) or with four or more positive axillary nodes (46 Gy to regional lymph nodes). Radiotherapy was delivered in two Gy fractions, five fractions per week. Adjuvant endocrine therapy was received by $44.8 \%$ of patients $(70.1 \%$ of patients with ER and/or PR positive tumours): $44.8 \%$ in the HER2 negative and $39.7 \%$ in the HER2 positive group. Tamoxifen was the predominant endocrine therapy.

Recurrence-free survival (RFS) was the primary outcome to access treatment efficacy and was defined as the interval elapsed between the date of surgery and the date of documented disease relapse. Overall survival (OS) was the secondary outcome, defined as the interval elapsed between the date of surgery and the date of death from breast cancer. RFS and OS distributions were estimated by the KaplanMeier method according to the HER2 status and the treatment regimen, and were compared using the log-rank test.

Median follow-up time was $32.1 \pm 10.1$ months (6.3-77.2). Sixty patients $(31.3 \%)$ experienced recurrence of the dis- ease. No differences in RFS were observed between patient groups with or without HER2 overexpression (43 vs 37.8 months, $P>0.05$ ). Kaplan-Meier survival curves were constructed for three-year RFS. Figure 1 summarises the results of the RFS comparison between CMF and anthracycline based chemotherapy in the two cohorts of HER2 overexpressed patients and patients without HER2 overexpression. It can be observed that in HER2 negative patients CMF is more effective than anthracycline-based chemotherapy (33.2 months (SD 1.308; 95\%CI 30.6-35.8) vs 26.9 months (SD 1.465; 95\%CI 23.9-29.4), $P<0.05$ ). In the HER2 overexpressed cohort it is suggested that anthracyclinebased chemotherapy can be more effective than CMF, although the number of patients was very small, and the difference was not significant (30 months (SD 2.170; 95\%CI 25.7-34.4) vs 29,2 months (SD 1.965; 95\%CI 25.4-33.1), $P<0,05)$.

HER2 positive
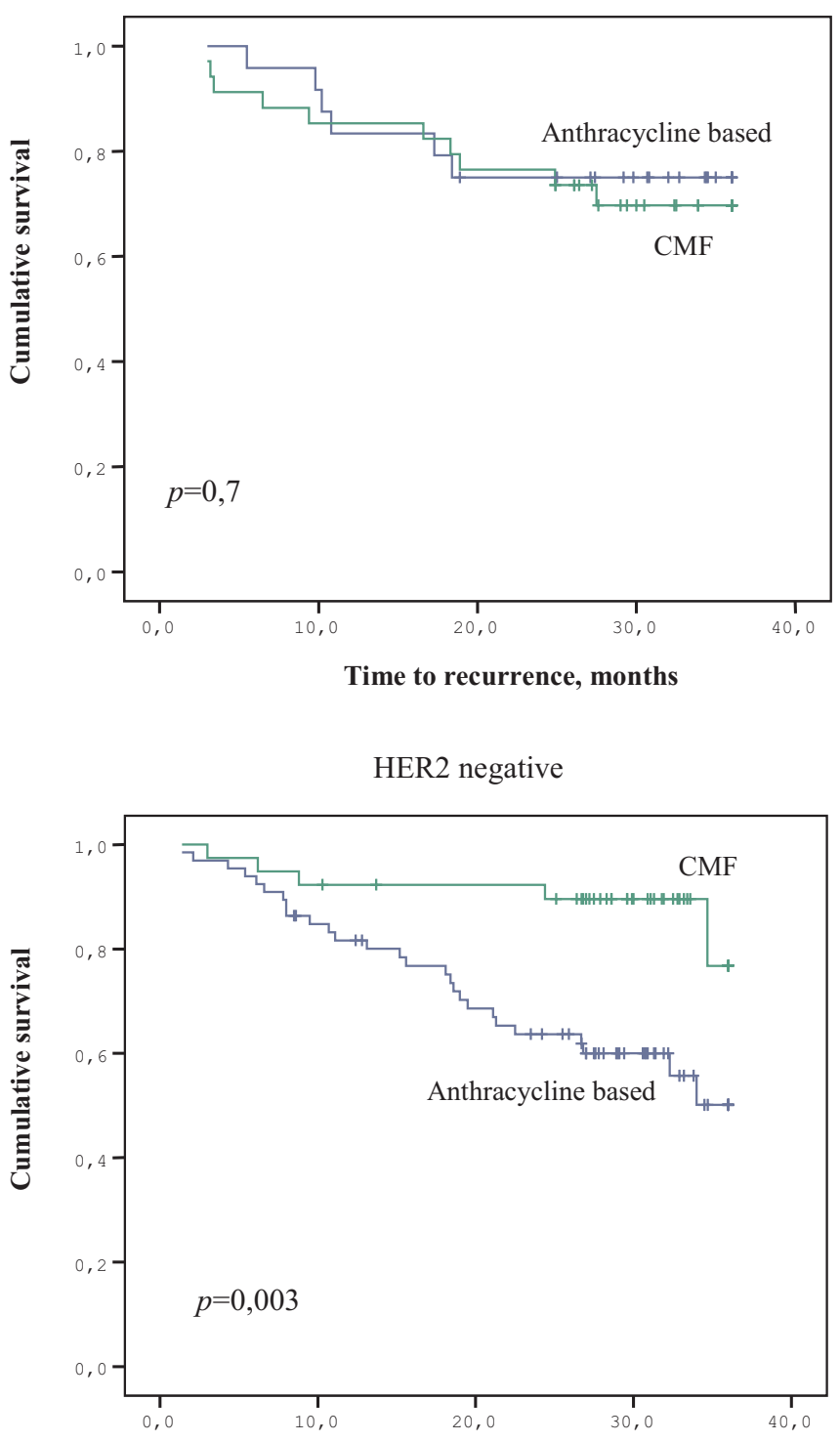

Time to recurrence, months

Fig.1. Three-year recurrence-free survival (RFS) according to HER2 status and chemotherapy type. 
A separate analysis was performed for patient groups with and without axillary lymph node metastases. In patients without HER2 overexpression, CMF significantly improves RFS in node positive (31.3 (95\%CI 26.9-35.8) vs 24.6 (95\%CI 20.8-28.5) months, $P<0,05$ ), as well as in node negative (35.4 (95\%CI 34.1-36.6) vs 31.0 (95\%CI 27.4-34.6), $P>0.05$ ) patients, while in HER2 overexpressed patients no significant difference in RFS was observed in node negative (32.6 (95\% CI 28.9-36.4) vs 33.2 (95\%CI 28.0-38.4) months, $P>0.05$ ), as well as in the node positive group of patients (24.4 (95\%CI 17.5-31.4) vs 28.1 (95\%CI 22.2-33.9) months, $P>0.05$ ).

Mean survival time was 58.8 months (SD 2.611; 95\%CI 53.7-63.9), median survival time was not reached yet. Twenty-eight (14.6\%) patients died of breast cancer. No differences in OS were observed between groups with or without HER2 overexpression (57.6 (95\%CI 50.4-64.8) vs 57.2 (95\%CI 50.9-63.6) months, $P>0.05$ ). Kaplan-Meier curves were constructed for three-year OS. Twenty-four deaths from breast cancer were observed. No differences were observed in HER2 negative $(P>0,05)$, nor in the HER2 overexpressed $(P>0.05)$ cohort of patients. Median survival time can not be estimated due to a small sample size.

Regarding axillary lymph node metastases, in patients without HER2 overexpression, there was no survival difference between CMF and anthracycline based chemotherapy in node negative (35.4 (95\%CI 34.2-36.5) vs 34.3 (95\% CI $31.8-36.7)$ months, $P>0.05)$ and in node positive $(33,3$ (95\%CI 30.4-36.1) vs 31.1 (95\%CI 28.2-34.0) months, $P>$ $0.05)$ group of patients. For patients with HER2 overexpression the mean survival cannot be calculated due to low mortality. There was a trend that HER2 positive, node positive breast cancer patients benefit from anthracycline based chemotherapy compared with $\mathrm{CMF}(P>0.05)$, but the difference was not significant, probably due to low sample size.

Oxford meta-analysis (Anonymous, 2005) 15 years followup results have demonstrated that anthracycline-based therapy is more effective than CMF regimen in the adjuvant therapy of breast cancer patients, although the absolute disease-free survival and overall survival benefits related to the use of anthracyclines are 3\% in five years and $4 \%$ in ten years. Anthracycline-based chemotherapy is associated with increased both short-term and long-term toxicities (Levine et al., 1998; Pinder et al., 2007). Treatment with anthracyclines is also more expensive than CMF therapy.

Different retrospective studies have suggested that an anthracycline-based adjuvant chemotherapy has the highest efficacy in the subgroup of breast cancer patients with HER2 overexpression (Dressler et al., 2005). Other investigators have examined the effect of HER2 amplification or overexpression on outcome in trials comparing regimens that contained an anthracycline with those that did not contain an anthracycline (Paik et al., 1998; De Laurentiis et al., 2001; Knoop et al., 2005; Pritchard et al., 2006). Although most, but not all, of these trials suggested a trend toward greater benefit with the anthracycline-containing regimen in women whose tumors overexpress HER2, tests for interaction were significant in only two studies-one for RFS (Paik et al., 1998), another for RFS and OS (Pritchard et al., 2006).

Pegram et al. (1997) investigated whether HER2 overexpression or amplification conferred a sensitivity to doxorubin in four breast cancer cell lines that were transfected with the HER2 gene and then exposed to doxorubicin. No alteration in chemosensitivity was observed in any of the lines. In addition, no association between HER2 amplification or overexpression and resistance to CMF or FEC, and no preferential benefit of an anthracycline-containing regimen in tumours positive for HER2 was found in an in vitro study (Konecny et al., 2001) of breast cancer cells obtained from 140 patients who had never received chemotherapy. These findings argue against a direct role of HER2 amplification or overexpression in the sensitivity of breast cancer to anthracyclines.

Anthracyclines are topoisomerase inhibitors. The association between HER2 overexpression or amplification and sensitivity to anthracycline may be related to topoisomerase II $\alpha$ (TOP2A) (Jarvinen and Liu, 2003), the TOP2A gene is located close to the HER2 gene on chromosome 17, and patients with simultaneous HER2 and TOP $2 A$ gene amplification derive the greatest benefit from anthracycline-based chemotherapy (Jarvinen et al., 2000; Harris et al., 2001).

The results of our study, which investigated the predictive value of HER2 expression by IHC in a population of early breast cancer patients treated with either an anthracyclinebased therapy or CMF, seem to support the concept of an interaction between HER2 overexpression and anthracycline efficacy. In the whole study population there was a trend favouring CMF over anthracycline-based therapy, even in node positive patients. In the cohort of HER2 overexpressed patients, the results suggest that this group of patients derive the greatest benefit from anthracycline-based therapy, but the number of patients was limited, and the difference did not reach statistical significance. Our suggestion is that breast cancer patients without HER2 overexpression could be treated with less toxic CMF chemotherapy without compromising RFS or OS.

Because of the limited number of patients analysed in the present study, no firm conclusions can be drawn regarding the predictive value of HER2 status in the adjuvant therapy of breast cancer.

\section{ACKNOWLEDGEMENTS}

The work has been supported by the European Social Fund.

\section{REFERENCES}

Anonymous (2005). Effects of chemotherapy and hormonal therapy for early breast cancer on reccurrence and 15-year survival: An overview of the randomised trials. Early Breast Cancer Trialists' Collaborative Group (EBCTCG) Lancet, 365 (9472), 1687-1717. 
De Laurentiis, M., Caputo, F., Massarelli, E., Forestieri, V., Vernaglia, A., Carlomagno, C., Lauria, R., Bianco, A.R., De Placido, S. (2001). HER2 expression and anthracycline effect: Results from the Naple GUN 3 randomized trial. Proc. Am. Soc. Clin. Oncol., 20, 34A (abstract 133).

Dressler, L.G., Berry, D.A., Broadwater, G., Cowan, D., Cox, K., Griffin, S., Miller, A., Tse, J., Novotny, D., Persons, D.L., Barcos, M., Henderson, I.C., Liu, E.T., Thor, A., Budman, D., Muss, H., Norton, L., Hayes, D.F. (2005). Comparison of HER2 status by fluorescence in situ hybridization and immunohistochemistry to predict benefit from dose escalation of adjuvant doxorubicin-based therapy in node-positive breast cancer patients. J. Clin. Oncol., 23(19), 4287-4297.

Gusterson, B.A., Gelber, R.D., Goldhirsch, A., Price, K.N., SaveSoderborgh, J., Anbazhagan, R., Styles, J., Rudenstam, C.M., Golouh, R., Reed, R. (1992). Prognostic importance of c-erbB-2 expression in breast cancer. International (Ludwig) Breast Cancer Study Group. J. Clin. Oncol., 10(7), 1049-1056.

Harris, L.N., Yang, L., Liotcheva, V., Pauli, S., Iglehart, J.D., Colvin, O.M., Hsieh, T. S. (2001). Induction of topoisomerase II activity after Erb B2 activation is associated with a differential response to breast cancer chemotherapy. Clin. Cancer Res., 7(6), 1497-1504.

Jarvinen, T.A., Liu, E.T. (2003). HER-2/neu and topoisomerase IIalpha in breast cancer. Breast Cancer Res. Treat., 78(3), 299-311.

Jarvinen, T.A.H., Tanner, M., Rantonen, V., Barlund, M., Borg, A., Grénman, S., Isola, J. (2000). Amplification and deletion of topoisomerase II associate with Erb B-2 amplification and affect sensitivity to topoisomerase II inhibitor doxorubicin in breast cancer. Amer. J. Pathol., 156(3), 839-847.

Knoop, A.S., Knudsen, H., Balslev, E., Rasmussen, B.B., Overgaard, J., Nielsen, K. V., Schonau, A., Gunnarsdottir, K., Olsen, K.E., Mouridsen, H., Ejlertsen, B. (2005). Retrospective analysis of topoisomerase IIa amplifications and deletions as predictive markers in primary breast cancer patients randomly assigned to cyclophosphamide, methotrexate, and fluorouracil or cyclophosphamide, epirubicin, and fluorouracil. J. Clin. Oncol., 23(30), 7483-7490.
Konecny, G., Fritz, M., Untch, M., Lebeau, A., Felber, M. , Lude, S., Beryt, M., Hepp, H., Slamon, D., Pegram, M. (2001). HER-2/neu overexpression and in vitro chemosensitivity to $\mathrm{CMF}$ and $\mathrm{FEC}$ in primary breast cancer. Breast Cancer Res. Treat., 69(1), 53-63.

Levine, M.N., Bramwell, H., Pritchard, K.I., Shepherd, L.E., Tu, D., Paul, N. (1998). Randomised trial of intensive cyclophosphamide, epirubicin, and fluorouracil chemotherapy compared with cyclophosphamide, methotrexate, and fluorouracil in premenopausal women with node-positive breast cancer. J. Clin. Oncol., 16(22), 2651-2658.

Paik, S., Bryant, J., Park, C., Fisher, B., Tan-Chiu, E., Hyams, D., Fisher, E.R., Lippman, M.E., Wickerham, D.L., Wolmark, N. (1998). erbB-2 and response to doxorubicin in patients with axillary lymph node-positive, hormone receptor-negative breast cancer. J. Natl. Cancer Inst., 90(18), 1361-1370.

Pegram, M.D., Finn, R.S., Arzoo, K., Beryt, M., Pietras, R.J., Slamon, D.J. (1997). The effect of HER-2/neu overexpression on chemotherapeutic drug sensitivity in human breast and ovarian cancer cells. Oncogene, 15(5), 537-547.

Pinder, M.C., Duan, Z., Goodwin, J.S., Hortobagyi, G.N., Giordano, S.H. (2007). Congestive heart failure in older women treated with adjuvant anthracycline chemotherapy for breast cancer. J. Clin. Oncol., 25(25), 3808-3815.

Pritchard, K.I., Shepherd, L.E., O'Malley, F.P., Andrulis, I.L., Tu, D., Bramwell, V. H., Levine, M.N. (2006). HER2 and responsiveness of breast cancer to adjuvant chemotherapy. N. Engl. J. Med., 354(20), 2103-2111.

Slamon, D.J., Godolphin, W., Jones, J.A., Holt, J.A., Wong, S.G., Keith, D.E., Levin, W.J., Stuart, S.G., Udove, J., Ullrich, A., Press, M.F. (1989). Studies of the HER-2/neu proto-oncogene in human breast and ovarian cancer. Science, 244(4905), 707-712.

Wolff, A.C., Hammond, M.E.H., Schwartz, J.N., Hagerty, K.L., Allred, D.C., Cote, R. J., Dowsett, M., Fitzgibbons, P.L., Hanna, W.M., Lager, A., McShane, L.M., Paik, S., Pegram, M.D., Perez, E.A., Press, M.F., Rhodes, A., Sturgeon, C., Taube, S. E., Tubbs, R., Vance, G.H., van de Vijver, M., Wheeler, T.M., Hayes, D.F. (2007). American Society of Clinical Oncology/College of American Pathologists Guideline Recommendations for Human Epidermal Growth Factor Receptor 2 Testing in Breast Cancer. $J$. Clin. Oncol., 25(1), 118-145.

Received 27 May 2008

\section{HER2 EKSPRESIJAS LOMA KRŪTS VĒŽA ADJUVANTĀS KৃĪMIJTERAPIJAS IZVĒLĒ}

Cilvēka epidermālā augšanas faktora receptora 2 (HER2) ekspresijai var būt nozīme, lai izvēlētos adjuvantu kịmijterapiju ar vai bez antraciklīniem pacientēm ar krūts vēzi. Pētījumā tika iekḷautas 192 pacientes, kurām Latvijas Onkoloğijas centrā laika posmā no 2002. gada janvāra līdz 2005. gada augustam tika diagnosticēts krūts vēzis. Galvenie iekḷaušanas kritēriji bija morfoloğiski verificēta krūts vēža diagnoze un imūnhistoḳīmiski noteikts HER2. Pacientēm bija izdarīta radikāla operācija un vismaz četri adjuvantas kīmijterapijas kursi. Vidējais novērošanas laiks bija 32,1 mēnesis. Pacientēm, kurām nebija novērota HER2 receptora pārmērīga ekspresija un kuras saṇēma kīmijterapiju ar antraciklīniem, vidējais laiks līdz recidīvam bija 26,9 mēneši (SD 1.465; 95\%CI 23,9-29,4), CMF grupā 33,2 mēneši (SD 1,308; 95\%CI 30,6-35,8), atškirība ir būtiska $(P<0,05)$, šìm pacientēm var rekomendēt mazāk toksisku CMF kīmijterapiju. Pacientēm ar HER2 receptora pārmērīgu ekspresiju, kuras sanēma k̦īmijterapiju ar antraciklīniem, vidējais laiks līidz recidīvam bija 30 mēneši (SD 2.170 ; 95\%CI 25,7-34,4) salīdzinājumā ar 29,2 mēnešiem (SD 1.965; 95\%CI 25,4-33,1) CMF kīmijterapijas grupā, atškirīiba nav būtiska $(P>$ $0,05)$. 